\title{
Turkish Version of the Multidimensional Index of Life Quality in Patients with Acute Coronary Syndrome
}

\section{Akut Koroner Sendromlu Hastalarda Çok Boyutlu Yaşam Kalitesi İndeksinin Türkçe Versiyonu}

(i) Şeyma DEMIR 1 , iD Zeynep ÖZER²

${ }^{1}$ Bolu Abant İzzet Baysal University Faculty of Health Sciences, Department of Nursing, Bolu, Turkey

2Akdeniz University Faculty of Nursing, Department of Nursing, Antalya, Turkey

\section{ABSTRACT}

Objective: Decreased quality of life is an important state in which patients with acute coronary syndrome (ACS) frequently experienced. Thus, measuring the quality of life of these patients is necessary. This study aimed to translate, cross-culturally adapt, and psychometrically test the Turkish version of the Multidimensional Index of Life Quality in patients with ACS.

Methods: The study sample consisted of 370 patients with ACS who were admitted to a university hospital between October 2010 and June 2011. In this cross-sectional study, backward and forward translation methods were used between the Turkish and English version of the scale. The following psychometric properties were evaluated: content validity, exploratory and confirmatory factor analyses, Cronbach's alpha coefficient, test-retest analysis, and equivalent forms method.

Results: Goodness-of-fit index (GFI) results of the confirmatory factor analysis indicated that the a priori hypothesized nine-factor model had a non-acceptable fit in the sample based on the following: $\chi 2=1854.58, \mathrm{df}=523, \chi 2 / \mathrm{df}=3.54 ; \mathrm{p}<0.001$; root mean-square error of approximation $=0.09$, standardized root mean residual $=0.09$, normed fit index $(\mathrm{NFI})=0.81$, non-NFI $=0.84, \mathrm{GFI}=0.71$; adjusted $\mathrm{GFI}=0.65$. The exploratory factor analysis showed six components with an eigenvalue of $>1.0$, explaining $69.7 \%$ of the cumulative variance. Cronbach's alpha coefficient was 0.94 for the total scale.

\section{ÖZ}

Amaç: Akut koroner sendromlu (AKS) hastalarda azalmış yaşam kalitesi önemli bir durumdur. Bu nedenle, hastalar için yaşam kalitesi ölçümlerinin yapılması yararlıdır. Bu çalışmada, AKS'li hastalarda çok boyutlu yaşam kalitesi indeksinin Türkçe'ye çeviri ve kültürlerarası uyarlama yapılması ve psikometrik olarak test edilmesi amaçlanmıştır.

Yöntemler: Araştırmanın örneklemini bir üniversite hastanesine Ekim 2010 ve Haziran 2011 tarihleri arasında başvuran 370 AKS'li hasta oluşturmuştur. Kesitsel tipteki çalışmada ölçeğin Türkçe ve İngilizce fomları arasında ileri-geri çeviri yöntemleri kullanılmıştır. Psikometrik özellikler kapsam geçerliği, açımlayıcı ve doğrulayıcı faktör analizi, Cronbach's alfa katsayısı, test-tekrar test analizi ve eşdeğer formlar yöntemi kullanılarak değerlendirildi.

Bulgular: Doğrulayıcı faktör analizinin uyum indeksi sonuçları, ölçeğin önceden belirlenmiş dokuz faktörlü model yapısını doğrulamadi: $\chi 2=1854.58, \mathrm{df}=523, \chi 2 / \mathrm{df}=3,54 ; \mathrm{p}<0,001$; RMSEA $=0,09$, SRMR $=0,09$, NFI $=0,81$, NNFI $=0,84$, GFI $=0,71$; AGFI =0,65. Açımlayıcı faktör analizi, özdeğeri 1,0'ın üzerinde olan ve toplam varyansın \%69,7'sini açıklayan altı bileşen ortaya çıkarmıştır. Cronbach's alfa katsayısı toplam ölçek puanı için 0,94 olarak bulunmuştur. Test-tekrar test analizi, ölçeğe uygulanan birinci ve ikinci test arasında anlamlı bir ilişki göstermiştir $(r=0,88$, $\mathrm{p}<0,001)$.
Address for Correspondence: Şeyma DEMiR, Bolu Abant İzzet Baysal University Faculty of Health Sciences, Department of Nursing, Bolu, Turkey

E-mail: seyma_demir@yahoo.com ORCID ID: orcid.org/0000-0003-4112-9161
Received: 17.12 .2019

Accepted: 18.02 .2020

Cite this article as: Demir Ş, Özer Z. Turkish Version of the Multidimensional Index of Life Quality in Patients with Acute Coronary Syndrome. Bezmialem Science 2021;9(1):61-7. 
The test-retest analysis found significant correlation between the first and second tests of the scale $(\mathrm{r}=0.88, \mathrm{p}<0.001)$.

Conclusion: The findings showed that the scale can be used to determine the level of the quality of life of Turkish patients with acute coronary syndrome.

Keywords: Multidimensional index of life quality, quality of life, reliability, validity
Sonuç: Bulgular, bu ölçeğin akut koroner sendromlu Türk hastaların yaşam kalitesini belirlemek için kullanılabileceğini göstermiştir.

Anahtar Sözcükler: Çok boyutlu yaşam kalitesi indeksi, yaşam kalitesi, güvenirlik, geçerlik

\section{Introduction}

Cardiovascular diseases (CVDs) are the primary cause of mortality worldwide. Acute coronary syndrome (ACS) among CVDs is responsible for 17.7 million deaths in 2015 (1) and is the most common cause of chest pain and emergency room admissions (2). ACS occurs due to inadequate blood circulation or atherosclerotic plaque rupture in the coronary arteries (3). ACS has three clinical manifestations based on the differences in diagnosis and treatment process: unstable angina, non-ST segment elevation myocardial infarction, and STEMI $(4,5)$. It is also a major health problem in Turkey. Among CVDs, ischemic heart diseases ranked first with approximately 64,000 deaths, which accounted for $38.4 \%$ of all deaths in 2018 (6). The increasing incidence of ACS and the high number of deaths reveal the social importance of this disease.

ACS is a debilitating health problem that causes various biopsychosocial complications (7). Despite being physically, mentally, and emotionally healthy in the first few months after an acute cardiac event $(8,9)$, patients can have poor healthrelated quality of life (HRQoL) in the succeeding years (10). In addition, patients' feelings and attitudes about life may change and decreased QoL can be observed, which is a part of the subjective well-being of the HRQoL (11). Decreased QoL is usually related to individual judgments about factors such as consequences of coronary invasive and surgical interventions for ACS, changes in the vascular structure and body organs with age, physical discomfort associated with chest pain, management of risk factors, effects of cardiac medication, uncertainty, difficulties in returning to work, perceived social support, and coping $(7,8,10)$. Therefore, it is useful that QoL is measurable.

HRQoL measurements that are frequently examined in Turkish studies are an important issue. Several general (EuroQol-5 Dimension, Nottingham Health Profile, 36-Item Short Form Survey, World Health Organization Quality of Life Instruments) and disease-specific instruments [Quality of Life IndexCardiac Version, MacNew, Myocardial Infarction Dimensional Assessment Scale-Turkey (MIDAS-TR)] have been used to assess different domains of HRQoL in patients with CVDs (12). However, they are less focused on the life satisfaction aspect. The multidimensional index of life quality (MILQ) is a general QoL instrument (13), and only its Dutch translation has been made from the original language (14). Studies have shown its use in patients with ACS $(9,15)$ as well as in various clinical situations or different populations (16-19). Through nine subdimensions, a multidimensional measurement of HRQoL is feasible with MILQ.

Therefore, MILQ can be administered to patients with ACS in Turkey. Through MILQ, the functional status and the emotional, cognitive, psychological, socioeconomic, and behavioral responses of individuals with ACS can be evaluated multidimensionally. Unlike other measurement tools, MILQ measures life satisfaction including relationship with health professionals. The use of the scale in these patients may contribute to determining the effects of the disease and its treatment on the daily lives of the individuals. The obtained results may contribute to the nursing care process and may direct nursing interventions. Therefore, MILQ, whose original study has been carried out in the USA and its original language is English, was translated into Turkish by using standard translation methods. This study aimed to translate, cross-culturally adapt, and psychometrically test the Turkish version of the MILQ in patients with ACS.

\section{Methods}

\section{Settings and Participants}

The Turkish version of the MILQ was administered in 370 patients. Adult patients with ACS from three cardiology clinics of the university hospital in South Turkey were invited to participate. For inclusion, patients should be 18-65 years old and do not have a chronic disease such as diabetes and chronic respiratory disease. Data were collected by the researcher between October 2010 and June 2011 through face-to-face interview with patients with ACS who met the sample criteria and agreed to participate in the study.

\section{Instruments}

The MILQ was developed by Avis et al. (13), which includes 35 items in the following nine subdimensions: mental health, physical health, physical functioning, cognitive functioning, social functioning, intimacy, productivity, financial status, and relationship with health professionals. Each sub-dimension has four items, but one item is included in two domains. MILQ has a seven-point Likert scale that ranges from 1 (very dissatisfied) to 7 (very satisfied). Its scores range from 4 to 28 for each subdimension, with higher scores showing better functioning or status. Cronbach's alpha coefficient is 0.89 for the total scale, and the sub-dimension coefficients range from 0.62 to 0.93 . 
The MIDAS-TR was used to test equivalent forms method. MIDAS was developed by Thompson et al. (20). Its Turkish validity and reliability study was performed by Uysal et al. (21). MIDAS-TR includes 35 items and six subdimensions: physical activity, insecurity, emotional reaction, social activity, dependency, and concern over medication (21). Its five-point Likert type scale was calculated by scoring between "0" (never) and " 4 " (always) (20). The score for each sub-dimension ranges from "0" (best possible health) through to "100" (worst health). Low scores indicate better QoL. Cronbach's alpha coefficients of the subdimensions range from 0.65 to 0.87 for MIDAS-TR, and the alpha for the total scale is 0.88 (21).

\section{Methodology of Translation and Procedures}

After the English version of the MILQ was provided by the website, authors obtained permission to adapt the Turkish version of the MILQ from Nancy Avis. The cross-sectional study was carried out with forward and backward translations. Then, the following language translation procedures were performed:

1. The MILQ was translated from English into Turkish (forward translation) by four experts (two instructors and two lecturers).

2. These translations were combined by the researchers, and the scale form was rearranged.

3. Thereafter, backward translation into English was performed by an independent translator and a lecturer who understood and spoke both languages (Turkish-English).

4. Language translations were compared, and appropriate expressions for the scale items were identified.

Then, five expert nurses gave their opinions of the content validity of the MILQ. The experts assessed the suitability of each item in the scale of over 10 points (item is suitable). Kendall's concordance (Wa) coefficient was calculated to determine whether the scale items were applicable or not. If the $\mathrm{p}$ value was greater than 0.05 , the scale items were considered valid.

\section{Ethical Considerations}

Ethical approval was obtained from the ethics committee (09.21.2010/117). The study was conducted in accordance with the Declaration of Helsinki and based on the voluntary principle. The participants were informed about the aim of the study and confidentiality of their personal information, and their consent was obtained.

\section{Data Analysis}

Data were analyzed using the Statistical Package for Social Sciences and Sensory Activation Solutions. Descriptive statistics were calculated with percentage, mean, and standard deviation. Construct validity was analyzed by performing confirmatory factor analysis (CFA) and explanatory factor analysis (EFA). Before, the Kaiser-Meyer-Olkin (KMO) and Bartlett's tests were peformed to examine the adequacy of the sample size for the factor analysis. In the CFA, several fit indices were used to identify the fitness of the model, including chi-square $\left(\chi^{2}\right)$ statistics, degrees of freedom (df), ratio of $\chi^{2}$ to $\mathrm{df}\left(\chi^{2} / \mathrm{df}\right)$, root- mean-square error of approximation (RMSEA), standardized root mean-square residual (SRMR), normed fit index (NFI), non-NFI (NNFI), goodness-of-fit index (GFI), adjusted GFI (AGFI). The factor extraction method was performed using the principal component analysis and varimax rotation for the EFA. Reliability was performed with Cronbach's alpha coefficient, test-retest, and equivalent forms method. Cronbach's alpha coefficient was used to determine internal consistency. For the test-retest analysis, 2 weeks after the administration of the first questionnaire, 50 participants responded to determine if there was no change over time. The test-retest reliability was calculated by Pearson correlation coefficient. A paired sample t-test was used to determine whether a statistical difference exists between the two tests. The $\mathrm{p}$ value was accepted as $>0.05$ for the t-test. The equivalent forms method was also calculated by identifying the correlation between MILQ and MIDAS-TR using the Pearson correlation coefficient. The $\mathrm{p}$ value was accepted as $<0.05$ for the correlation coefficient.

\section{Results}

The majority of the patients, with a mean age of $58.63 \pm 7.76$ years, were male $(75.4 \%)$. Most of the patients were married (93.8\%) and have a social security (99.2\%). Moreover, 51.9\% of the participants were followed up for MI, and $32.7 \%$ of them have less than 1 year of disease diagnosis. In this study, $65.7 \%$ of the patients were hospitalized once due to heart diseases. While $63.2 \%$ of the patients stated that they were on a diet therapy, $65.1 \%$ did not exercise. The most common symptoms were chest pain $(9.0 \%)$ and fatigue $(22.4 \%)$.

\section{Validity}

Kendall's Wa value was statistically compatible with the applicability of the scale elements for the content validity $(\mathrm{p}=0.063)$. The KMO value was 0.93 , and Bartlett's test of sphericity was at the significance level $(\chi 2=9931.43, \mathrm{df}=595$, $\mathrm{p}<0.001)$. In the CFA, the goodness-of-fit indices were as follows: $\chi 2=1854.58, \mathrm{df}=523, \chi 2 / \mathrm{df}=3.54, \mathrm{p}<0.001, \mathrm{RMSEA}=0.09$, $\mathrm{SRMR}=0.09, \quad \mathrm{NFI}=0.81, \quad \mathrm{NNFI}=0.84, \quad \mathrm{GFI}=0.71, \quad$ and AGFI=0.65. In the EFA, the principal component analysis and varimax rotation indicated that the factor loading of item 9 was 0.19 . Item 9 was then deleted from the scale, and EFA was performed again with 34 items. Six factors with eigenvalues of $>1.00$ were identified. Factor 1 (15 items-items 5, 6, 8, 10, 11, $12,14,15,20,21,22,24,33,34$, and 35), factor 2 (4 itemsitems 1, 2, 3, and 4), factor-3 (5 items-items 28, 29, 30, 31, and 32), factor 4 ( 4 items-items $7,13,18,19$, and 23), factor 5 (3 items-items 25, 26, and 27) and factor 6 (two items-items 16 and 17). All of the six factors explained $69.7 \%$ of the cumulative variance (Table 1).

\section{Reliability}

Cronbach's alpha coefficient for the 34-item MILQ-TR was 0.94 , and the coefficients for the subscales ranged from 0.72 to 0.94 . Factor $1(\alpha=0.93)$ and factor $2(\alpha=0.93)$ subscales had the highest internal consistency coefficients, while factor 6 had the lowest $(\alpha=0.72)$ (Table 1$)$. In the test-retest reliability 
Table 1. Factor Structure of the 34-Item MILQ-TR

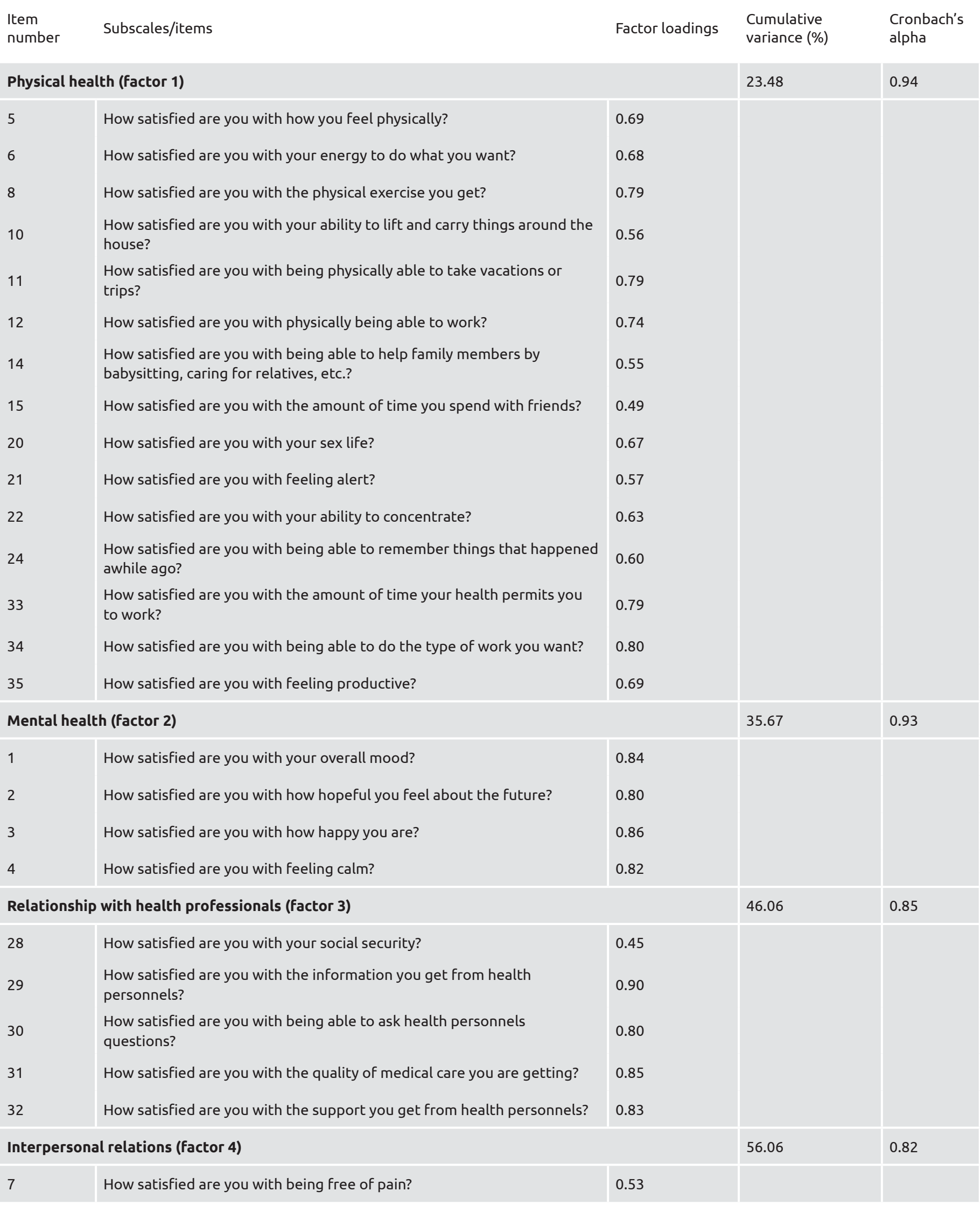


Table 1 contiuned

\begin{tabular}{|c|c|c|c|c|}
\hline 13 & $\begin{array}{l}\text { How satisfied are you with your family letting you do the things you } \\
\text { want? }\end{array}$ & 0.60 & & \\
\hline 18 & $\begin{array}{l}\text { How satisfied are you with the amount of affection your spouse/partner } \\
\text { expresses toward you? }\end{array}$ & 0.80 & & \\
\hline 19 & $\begin{array}{l}\text { How satisfied are you with being able to confide in your spouse/ } \\
\text { partnerthe amount of wantg do th? }\end{array}$ & 0.79 & & \\
\hline 23 & How satisfied are you with your ability to make decisions by yourself? & 0.61 & & \\
\hline \multicolumn{3}{|c|}{ Financial status (factor 5) } & 63.56 & 0.84 \\
\hline 25 & How satisfied are you with your financial income? & 0.84 & & \\
\hline 26 & How satisfied are you with your ability to pay monthly expenses? & 0.86 & & \\
\hline 27 & How satisfied are you with the amount of money you have in savings? & & & \\
\hline \multicolumn{3}{|c|}{ Social functioning (factor 6) } & 69.77 & 0.72 \\
\hline 16 & How satisfied are you with participating in community activities? & 0.68 & & \\
\hline 17 & $\begin{array}{l}\text { How satisfied are you with the activities you do with your spouse/ } \\
\text { partner? }\end{array}$ & 0.68 & & \\
\hline \multicolumn{5}{|c|}{ Cumulative variance $=69.7 \%$ (MILQ-TR) } \\
\hline \multicolumn{5}{|c|}{ Cronbach's alpha =0.94 (MILQ-TR) } \\
\hline
\end{tabular}

analysis, positive, high-level, and significant correlation was found between the first and second tests of the MILQ ( $r=0.88$, $\mathrm{p}<0.001)$. In the paired sample $\mathrm{t}$ test, the $\mathrm{p}$ value was 0.69 (Table 2). The correlation between MILQ-TR and MIDAS-TR was negative, moderate, and statistically significant $(r=-0.42$, $\mathrm{p}<0.001)$. The correlation coefficients between the MIDAS-TR and MILQ-TR subdimensions were $-0.39,-0.42,-0.08,--0.28$, -0.27 , and -0.13 , respectively.

\section{Discussion}

In this study, the psychometric properties of the 35-item MILQ were investigated. Significant findings were obtained, but since only the English version of the MILQ could be obtained, the comparison was made through a single study.

Factor analysis plays a key role in the validation of assessment scale data. In a previous study, KMO and Bartlett's test were used to examine the adequacy of the sample size for the factor analysis (22). If the KMO index is at least 0.05 and Bartlett's test is significant $(\mathrm{p}<0.05)$, it is considered suitable for the factor analysis (23). CFA is used when the goal is to test the validity of a hypothesized model of factors and the relationships of those factors to a set of observed variables. Numerous inferential and descriptive fit indices assist the evaluation of the goodness-of-fit of a CFA model as a whole (24). For a good model, the $\chi^{2} / \mathrm{df}$ ratio should be low $(\leq 3)$ and have a statistically insignificant $\mathrm{p}$ value for $\chi^{2}$. The $\chi^{2} / \mathrm{df}$ ratio of the current model was 3.54, and the $\mathrm{p}$ value was $<0.001$. The acceptable compliance for the RMSEA should be 0.05-0.08 and that for SRMR should be $\leq 0.05$ (25). For good model compliance, both conditions were not met in this study (RMSEA=0.09, SRMR=0.09). The NFI, NNFI, GFI, and AGFI should be $>0.90$ for model compliance. These fit indices were not also met in this study: NFI=0.81, NNFI=0.84, GFI=0.71, and $A G F I=0.65$. The NFI, GFI, and AGFI are sensitive to the sample size and can reject a good-compliance model (26). In this study, fit indices showed that the 9-factor MILQ is not suitable for the Turkish population. In the implementation of a scale to two different cultures, participants can be influenced by culturedriven trends.

Table 2. Comparisons of test-retest reliability coefficient and mean scores for the MILQ-TR

\begin{tabular}{|c|c|c|c|c|}
\hline & $\begin{array}{l}\text { Time } 1 \\
\text { mean } \pm \text { SD }\end{array}$ & $\begin{array}{l}\text { Time } 2 \\
\text { mean } \pm \text { SD }\end{array}$ & $r / p^{b}$ & $t / p^{c}$ \\
\hline MILQ & $182.20 \pm 33.60$ & $183.10 \pm 29.80$ & $0.88 /<0.001$ & $0.397 / 0.69$ \\
\hline \multicolumn{5}{|c|}{$\begin{array}{l}\text { aValues are expressed as mean } \pm \text { SD. } \\
{ }^{b} p<0.001 . \\
{ }^{c} p>0.05 \text {. } \\
\text { MILQ-TR: Turkish version of the Multidimensional Index of Life Quality; SD: Standard deviation }\end{array}$} \\
\hline
\end{tabular}


In this study, EFA was performed twice. In the first analysis, item 9 was removed from the scale because the factor loading was $<0.40$ (23). In the second analysis, the 34-item MILQ-TR showed a six-factor structure. A difference was found according to the factor structure of the original scale. While the original MILQ has nine subdimensions, the Turkish scale has six subdimensions. These subdimensions include physical health, mental health, and relationship with health professionals. However, the scale was found to show significant consistency in reflecting cultural values when the items under each factor are examined.

Reliability means that the same conceptual structure is measured consistently between independent measurements (23). Cronbach's alpha coefficient was used to measure internal consistency. The alpha value obtained for all items indicates the total reliability of the questionnaire. The generally acceptable alpha value is $\geq 0.70$, but it should be $>0.90$ for excellent consistency (27). The alpha coefficient was 0.94 for the total MILQ-TR. The alpha coefficients of the six factors were also above the desired value. In the English MILQ, the alpha coefficient of all subscales, except of social functioning, was $\geq 0.76$ (13). The high alpha value of the MILQ-TR indicates that the characteristics to be measured with the original scale can be measured consistently for the Turkish population. This finding suggests that the scale items are consistent with each other even when applied to a Turkish population.

Test-retest reliability refers to the degree to which the measure is able to differentiate between participants under repeated administrations of the measure under the same or similar conditions (28). In this study, high-level and significant correlations were found in the measurements performed with 2 -week intervals $(\mathrm{r}=0.88, \mathrm{p}<0.001)$. However, the statistically insignificant $\mathrm{p}$ value for the $\mathrm{t}$ test showed that the two tests remained constant over time (23). The characteristics to be measured by the scale items did not change with time in the Turkish population. Equivalent forms reliability examines the correlations between scores obtained by applying two or more forms of a test to the same individuals. The acceptable correlation coefficient for the equivalent forms reliability is considered $\geq 0.80$ (29). Poor-moderate level, negative, and significant correlations were determined between the MILQ-TR and MIDAS-TR. This finding can be interpreted as a less appropriate equivalent form of MIDAS-TR for the MILQ-TR. In further studies with MILQTR, high correlations can be obtained by testing a different version of the scale.

\section{Study Limitations}

Although sufficient and significant findings were obtained in this study, certain limitations were encountered. First, testing of the MILQ adapted to different cultures and languages was not performed. Thus, cross-cultural comparisons were carried out only based on the original work that developed MILQ. Second, in the scale validation and development studies, the sample group should be divided into two groups: the first group should be tested for the CFA and the second group for EFA, synchronously. In this study, the sample size was insufficient for this analysis.
Hence, CFA and EFA were tested in the same sample. Further studies should be conducted with a larger sample, and we can recommend re-testing of the CFA.

\section{Conclusion}

The findings support that the MILQ-TR generally has adequate validity and reliability to measure the HRQoL of Turkish patients with ACS. Importantly, this study will set as an example for cross-cultural adaptation conducted over the same scale in the future. The use of the scale will help determine the effects of disease and treatment on the daily lives of the individuals.

QoL measurement studies related to ACS have gained the interest of researchers. Indeed, QoL measurements are a key determinant of the health outcomes of these patients. However, in previous studies, all aspects of the QoL that may affect the health of individuals have not been examined. This study presents the aspects of QoL that have not been previously examined for these patients. The current scale can provide a multidimensional measurement of the QoL of individuals with CVDs.

\section{Ethics}

Ethics Committee Approval: Ethical approval was obtained from the ethics committee (09.21.2010/117).

Informed Consent: The participants were informed about the aim of the study and confidentiality of their personal information, and their consent was obtained.

Peer-review: Externally peer reviewed.

\section{Authorship Contributions}

Concept: Ş.D., Z.Ö., Design: Ş.D., Z.Ö., Data Collection or Processing: Ş.D., Analysis or Interpretation: Ş.D., Z.Ö., Literature Search: Ş.D., Z.Ö., Writing: Ş.D., Z.Ö.

Conflict of Interest: No conflict of interest was declared by the authors.

Financial Disclosure: The authors declared that this study received no financial support.

\section{References}

1. World Health Organization. World health statistics 2018: monitoring health for the SDGs, sustainable development goals (cited 2019 March 11). Available from: https:/www.who.int/gho/publications/ world_health_statistics/2018/en/.

2. Lashari NA, Lakho NI, Memon SA, Ahmed A, Waseem MF. Acute coronary syndrome. Professional Med J 2017;24:409-13.

3. Oriolo V, Albarran JW. Assessment of acute chest pain. British Journal of Cardiac Nursing 2010;5:587-93.

4. Dias CM, Macedo LB, Gomes LT, de Oliveira PL, Albuquerque IV, Lemos AQ, et al. Quality of life of patients after an acute coronary event: hospital discharge. J Clin Med Res 2014;6:362-8.

5. Humphreys M. Nursing the Cardiac Patient. West Sussex: John Wiley \& Sons; 2011. 
6. Türkiye İstatistik Kurumu. Ölüm Nedeni İstatistikleri, 2018. (cited 2019 March 11). Available from: http://www.turkstat.gov.tr/ HbPrint.do?id=27620.

7. Taghadosi M, Ghanbari-Afra L, Ghanbari-Afra M, Gilasi HR. Quality of life and its influencing factors in patients with acute coronary syndrome. Nursing Practice Today 2016;3:63-9.

8. Kristofferzon ML, Löfmark R, Carlsson M. Perceived coping, social support, and quality of life 1 month after myocardial infarction: a comparison between Swedish women and men. Heart Lung 2005;34:39-50.

9. Staniūtė M, Brožaitienė J. Changes in health-related quality of life among patients with coronary artery disease: a 2-year follow-up. Medicina 2010;46:843-50.

10. Rančić N, Petrović B, Apostolović S, Kocić B, Ilić M. Health-related quality of life in patients after the acute myocardial infarction. Open Medicine 2013;8:266-72.

11. Tate DG, Forchheimer M. Quality of life, life satisfaction, and spirituality: Comparing outcomes between rehabilitation and cancer patients. Am J Phys Med Rehabil 2002;81:400-10.

12. Demir Ş, Özer Z. Kardiyovasküler Hastalıklarda Yaşam Kalitesinin Değerlendirilmesi. Medical Network Cardiol 2014;21:182-91.

13. Avis NE, Smith KW, Hambleton RK, Feldman HA, Selwyn A, Jacobs A. Development of the Multidimensional Index of Life Quality: a quality of life measure for cardiovascular disease. Medical Care 1996;34:1102-20.

14. van Mastrigt GA, Joore MA, Nieman FH, Severens JL, Maessen JG. Health-related quality of life after fast-track treatment results from a randomized controlled clinical equivalence trial. Quality of Life Research 2010;19:631-42.

15. Sleeper LA, Ramanathan K, Picard MH, Lejemtel TH, White HD, Dzavik V, et al; SHOCK Investigators. Functional status and quality of life after emergency revascularization for cardiogenic shock complicating acute myocardial infarction. J Am Coll Cardiol 2005;46:266-73.

16. Avis NE, Smith KW. Quality of life in older adults with HIV disease. Res Aging 1998;20:822-45.

17. Blinderman CD, Homel P, Billings JA, Tennstedt S, Portenoy RK. Symptom distress and quality of life in patients with advanced chronic obstructive pulmonary disease. J Pain Symptom Manage 2009;38:115-23.

18. Smith KW, Larson MJ. Quality of life assessments by adult substance abusers receiving publicly funded treatment in Massachusetts. Am J Drug Alcohol Abuse 2003;29:323-35.

19. Strada EA, Homel P, Tennstedt S, Billings JA, Portenoy RK. Spiritual well-being in patients with advanced heart and lung disease. Palliat Support Care 2013;11:205-13.

20. Thompson DR, Jenkinson C, Roebuck A, Lewin RJ, Boyle RM, Chandola T. Development and validation of a short measure of health status for individuals with acute myocardial infarction: the myocardial infarction dimensional assessment scale (MIDAS). Qual Life Res 2002;11:535-43.

21. Uysal H, Özcan Ş, Enç N. Adaptation of Myocardial Infarction Dimensional Assessment Scale to Turkish: a validity and reliability study. Turk Kardiyol Dern Ars 2009;37:543-50.

22. Watson JC. Establishing evidence for internal structure using exploratory factor analysis. Measurement and Evaluation in Counseling and Development 2017;50:232-8.

23. LoBiondo-Wood G, Haber J. Nursing research, methods, appraisal and utilization. St Louis: Mosby Elsevier; 2002.

24. Dimitrov DM. Statistical methods for validation of assessment scale data in counseling and related fields. USA: John Wiley \& Sons; 2014.

25. Çelik HE, Yılmaz V. LISREL 9.1 ile yapısal eşitlik modellemesi: Temel kavramlar-uygulamalar-programlama. Ankara: Anı Yayıncılık; 2016.

26. Byrne B. Structural equation modelling with AMOS: Basic concepts, application, and programming. 3rd ed. New York: Taylor \& Francis Group; 2016.

27. George D, Mallery P. SPSS for windows step by step: A simple guide and reference, 11.0 update. 4th ed. Boston: Allyn \& Bacon; 2003.

28. Barton B, Peat J. Medical statistics: A guide to SPSS, data analysis and critical appraisal. 2nd ed. West Sussex: John Wiley \& Sons; 2014.

29. Fawcett AJL. Principles of assessment and outcome measurement for occupational therapists and physiotherapists: theory, skills and application. West Sussex: John Wiley \& Sons; 2007. 